\title{
Eburnean deformation pattern of Burkina Faso and the tectonic significance of shear zones in the West African craton
}

\author{
Dominique Chardon ${ }^{1,2,3, *}$, Ousmane Bamba ${ }^{1}$ and Kalidou Traoré ${ }^{1,2,4}$ \\ ${ }^{1}$ Département des Sciences de la Terre, Université Joseph Ki-Zerbo, Ouagadougou, Burkina Faso \\ 2 IRD, Ouagadougou, Burkina Faso \\ ${ }^{3}$ GET, Université de Toulouse, IRD, CNRS, UPS, CNES, Toulouse, France \\ ${ }^{4}$ Laboratoire de cartographie, DER de Géologie, FST, Université des Sciences, des Techniques et des Technologies de Bamako, \\ Bamako, Mali
}

Received: 11 March 2019 / Accepted: 24 December 2019

\begin{abstract}
Shear zones of the Paleoproterozoic Eburnean accretionary Orogen (West African craton) are investigated by means of large-scale structural mapping. Regional scale $(10-100 \mathrm{~km})$ mapping was based on the aeromagnetic survey of Burkina Faso and craton-scale $(1000 \mathrm{~km})$ mapping on a compilation of fabric data. At both scales, shear zones are arranged as an anastomosed transpressional network that accommodated distributed shortening and lateral flow of the orogenic lithosphere between the converging Kénéma-Man and Congo Archean provinces. Structural interference patterns at both scales were due to three-dimensional partitioning of progressive transpressional deformation and interactions among shear zones that absorbed heterogeneities in the regional flow patterns while maintaining the connectivity of the shear zone network. Such orogen-scale kinematic patterns call for caution in using the deformation phase approach without considering the "bigger structural picture" and interpreting displacement history of individual shear zones in terms of plate kinematics. The West African shear zone pattern is linked to that of the Guiana shield through a new transatlantic correlation to produce an integrated kinematic model of the Eburnean-Transamazonian orogen.
\end{abstract}

Keywords: hot orogen / shear zone pattern / Eburnean / Transamazonian / aeromagnetic data

Résumé - Champ de déformation éburnéen du Burkina Faso et signification tectonique des zones de cisaillement du craton ouest africain. Une cartographie structurale à grande échelle a été entreprise dans le but d'étudier les zones de cisaillement de l'orogène éburnéen (paléoprotérozoïque) du craton ouest africain. La cartographie d'échelle régionale $(10-100 \mathrm{~km})$ a été réalisée à l'échelle du Burkina Faso grâce à l'interprétation d'un relevé aéromagnétique et la cartographie d'échelle cratonique (1000 km) à partir d'une compilation de données structurales. Aux deux échelles, les zones de cisaillement définissent un réseau anastomosé transpressif ayant accommodé le raccourcissement distribué et le fluage latéral de la lithosphère orogénique entre deux provinces archéennes convergentes (Kénéma-Man et Congo). Aux deux échelles, les structures d'interférence résultent d'un partitionnement tridimensionnel progressif de la déformation transpressive et des interactions entre zones de cisaillement qui ont absorbé les hétérogénéités générées dans le fluage régional tout en maintenant la connectivité du réseau de cisaillements. Un tel schéma cinématique à l'échelle de l'orogène appelle à la prudence dans l'usage des phases de déformation sans considérer la déformation à très grande échelle et l'interprétation des zones de cisaillement en termes de cinématique de plaques. Le réseau de zones de cisaillement ouest africain est repositionné vis-à-vis de celui du craton guyanais via une nouvelle reconstruction transatlantique pour produire un modèle cinématique intégré de l’orogène éburnéen-transamazonien.

Mots clés : orogène chaud / réseau de zones de cisaillement / eburnéen / transamazonien / données aéromagnétiques

\footnotetext{
*Corresponding author: dominique.chardon@ird.fr
} 


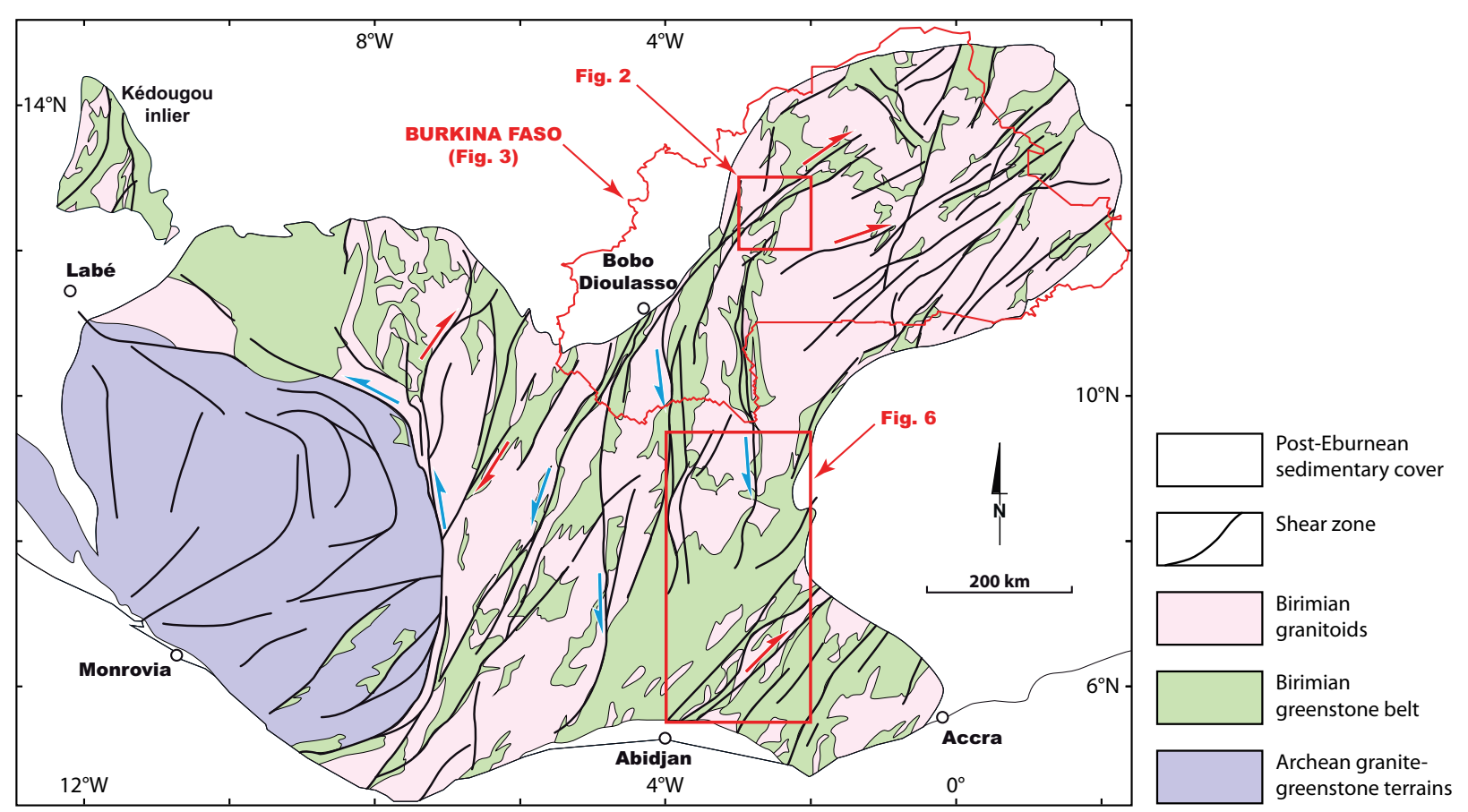

Fig. 1. Sketch structural map of the southern West African craton (after Milési et al., 1989 and Thiéblemont, 2016). In the original model of Milési et al. (1989), the dextral shear zones (red kinematic arrows) are the latest and related to a regional D3 strike-slip deformation event, whereas sinistral ones (blue kinematic arrows) would be related to a D2 strike-slip regional deformation event.

\section{Introduction}

The record and geodynamic meaning of tectonic strain in Precambrian accretionary orogens are matters of renewed interest and debate. Main issues are the nature of the mountain building processes and whether all or part of those processes are the signature of modern-like plate tectonics. In absence of crustal-scale thrusts such as those documented in modern collision belts, the ubiquitous transpressive shear zones of Precambrian accretionary orogens (Cagnard et al., 2006a; Chardon et al., 2009; Duguet et al., 2009) are central to the debate. In particular, whether they record large displacement or could be tight to a far-field kinematic framework or to a kind of plate kinematics is not straightforward (Treloar and Blenkinsop, 1995; Hanmer et al., 1997; Gapais et al., 2005; Chardon et al., 2008; Harris and Bédard, 2014). Those shear zones also tend to control the location of endogenous mineral deposits as typified by orogenic gold (e.g., Bedeaux et al., 2017; Gapais, 2018). Characterization of shear zones geometries and kinematics at various scales should therefore be useful to link local deformation histories with orogen-scale processes and mineral systems.

In this contribution, we address the relationships among deformation, shear zone patterns and kinematic boundary conditions of Precambrian accretionary orogens from the regional $(100 \mathrm{~km})$ to the orogen $(1000 \mathrm{~km})$ scale. Our study is based on the example of the Paleoproterozoic Eburnean orogen, one of the largest accretionary orogens preserved on Earth. The study focuses on the largest outcrop of the orogen found in the southern West African craton (sWAC; Fig. 1). We produced a structural map at the scale of Burkina Faso (ca. $500 \times 400 \mathrm{~km}$ ) by interpreting aeromagnetic data (Betts et al., 2007), and a craton-scale map (ca. $1200 \times 800 \mathrm{~km}$ ) obtained by compiling fabric data from geological maps. Finally, a new transatlantic correlation is proposed between the sWAC and the Guiana shield to produce a structural map on a mega scale (ca. $2000 \times 6000 \mathrm{~km}$ ) and evaluate the first-order structures and kinematics of the Eburnean-Transamazonian orogen. Our results show how regional shear zone patterns can be used as a gauge of orogen-scale deformation.

\section{Outline of the geological-structural context}

The Eburnean orogen of the sWAC affects the so-called Birimian crust, which consists of tholeitic to calc-alkalcaline mafic volcanics (preserved in greenstone belts that also comprise clastic sediments) and broadly coeval and younger TTG-like complexes and granitoid plutons (Milési et al., 1989, 1992; Block et al., 2016a; Parra-Avila et al., 2017, 2018; Wane et al., 2018; Grenholm et al., 2019). Birimian mafic and felsic magmatism and Eburnean deformation and metamorphism took place essentially between 2.27 and $1.96 \mathrm{Ga}$ (Grenholm et al., 2019). The Birimian crust is dominantly juvenile (Abouchami et al., 1990; Boher et al., 1992) with an increasingly documented Pre-Birimian Paleoproterozoic and Archean components of crustal inheritance, especially approaching its bounding Archean terrains (Eglinger et al., 2017; Parra-Avila et al., 2018; Petersson et al., 2018). The sWAC also exposes Archean terrains (in the Kénéma-Man domain), which have been involved in the Eburnean orogeny (Feybesse and Milesi, 1994; Fig. 1). 
The original regional-scale kinematic model of the Eburnean orogen favors late, two-phase strike-slip-dominated deformation through the shear zone network shown on Figure 1 (Milési et al., 1989; Feybesse and Milesi, 1994; Ledru et al., 1994; Lompo, 2010). Pre-strike-slip deformation inferred by most authors is a matter of debate, as usually in granite-greenstone terrains. Steep fabrics in greenstone belts were interpreted as:

- originally shallow fold and thrust fabrics that were steepened and/or transposed by strike-slip deformation (e.g., Feybesse and Milesi, 1994);

- resulting from vertical tectonism due to diapirism (Vidal et al., 2009; Lompo 2010).

Specific greenstone lithologies have been shown to preserve relics of HP-LT metamorphism, whereas regional HT-LP metamorphism associated with partial melting and felsic plutonism took place mostly during strike-slip dominated deformation (Ganne et al., 2014). Over the last decade, the "phase" or "event" structural approach was adopted by most authors using fabric, fold or shear orientations and their relative chronology to infer successive horizontal shortening (or stretching) directions (review in Grenholm et al., 2019). The tectonic significance of such directions is not straightforward, especially while attempting regional correlations amongst "events", which are implicitly taken as indicating changes in far-field convergence (or divergence) direction at the boundaries of the orogen. The large-scale mapping approach proposed here will provide an opportunity to replace such studies in a broader structural perspective.

\section{Deformation pattern at the scale of Burkina Faso}

\subsection{Data and method}

Regional geological - structural mapping of Birimian terrains by means of aeromagnetic data has proven to be useful to complement field investigations (Vegas et al., 2008; Metelka et al., 2011; Jessell et al., 2012; McFarlane et al., 2019), particularly because the West African context provides uneven lateral outcrop continuity due to an extensive lateritic cover (Chardon et al., 2018). In the present study, we used the aeromagnetic cover of Burkina Faso acquired in the course of the SYSMIN project (System for Mineral Products) at a pixel size of $250 \mathrm{~m}$ (see Metelka et al., 2011; Fig. 2a). The image represents the total magnetic intensity, overlaid on a grey-scale shaded relief image of its first vertical derivative (Fig. 2a).

We manually extracted the magnetic form lines (i.e., magnetic fabrics), which are expressed by the ridge-andtrough pattern of the image (Fig. $2 \mathrm{a}$ and $\mathrm{b}$ ). The ridges and the troughs, which can be several tens of $\mathrm{km}$ long, mark lateral contrasts in both the total magnetic intensity (color scale) and its derivative (hillshade). At first sight, magnetic fabrics would appear to express a lithological layering of contrasted magnetic properties. However, locally high-angle crosscutting relationships between the foliation and greenstone belt boundaries (Fig. 2b) indicate that it is not only a lithological fabric. Given the generally good agreement between magnetic fabric trajectories and the field measurements of foliation and cleavage (Fig. 2b), the magnetic fabric is interpreted to mark essentially the foliation or schistosity of the rocks that commonly coincides with the lithological banding to form a composite ("S0-1") fabric. Extraction of magnetic fabric trajectories on a regional scale by a single operator aims to provide a harmonized view of the strain pattern that would not be biased by an unevenly distributed regolith cover or by the contrasted interpretations of independent cartographers having worked in distant areas. Post-Eburnean mafic dikes have a distinctive signature of very strong, rectilinear and broken anomalies (Fig. 2e). They are omitted on the produced structural map.

The qualitative geometrical analysis of the magnetic fabric traces allowed for the identification of strain gradients indicative of shear zones (Martelat et al., 2000; Chardon et al., 2008). The mapping of those shear zones was made based on the shape of the fabric trajectories and their convergence/divergence patterns, their deflection, truncation, clustering and rectilinearity patterns (Fig. $2 \mathrm{~b}$ and c). A comparison of the interpretative shear zone traces with those of published maps (Chèvremont et al., 2003; Baratoux et al., 2011) shows an overall good agreement (Fig. 2c and d). But the enhanced lateral continuity of the structural magnetic mapping further allows refining the shear zone pattern by:

- enhancing the kinematic coherency and connectivity of the fabrics and shear zones;

- disregarding earlier interpretative shear zones of too limited length or cutting across continuous and undisturbed magnetic fabric beams to have a kinematic meaning;

- disregarding late- and post-tectonic fractures and faults that have no link to the regional ductile strain field.

Field kinematic criteria are consistent with deflection patterns of the magnetic fabrics along the newly mapped shear zones (e.g., sinistral along the N-trending shear system cutting the entire map area and dextral along the NE-trending shear system in the northeastern part; Fig. $2 \mathrm{~b}$ and c). The resulting fabric/shear zone map of Burkina Faso (Fig. 3) is complemented in Northern Ghana by the shear zone pattern mapped by Block et al. (2016b).

\subsection{Fabric and shear zone patterns}

The regional structural grain underlined by the fabric trajectories is dominantly NE trending (Fig. 3). The shear zones are mostly arranged as an anastomosed network delimitating lower-strain shear lenses. Almost all shear zones branch onto the neighboring shear zone(s) at an acute angle. This is even the case for the longest shear zones. For instance, the Ouahigouya shear zone bends eastward north of Ouahigouya to be taken into the arched Baraloubé shear zone, which branches onto the NE-trending Gorom Gorom shear zone around $1 \mathrm{~W}$ (Fig. 3). The shear zone also merges with the Fada N'Gourma shear zone in Ghana (Block et al., 2016b; see section 4). The systematic anastomosed branching pattern and the connectivity of the shear zones suggest that no individual shear zone did strictly outlast slip along its nearest neighbor(s) and that kinematic coherency has been maintained within the shear zone network throughout the deformation history. 

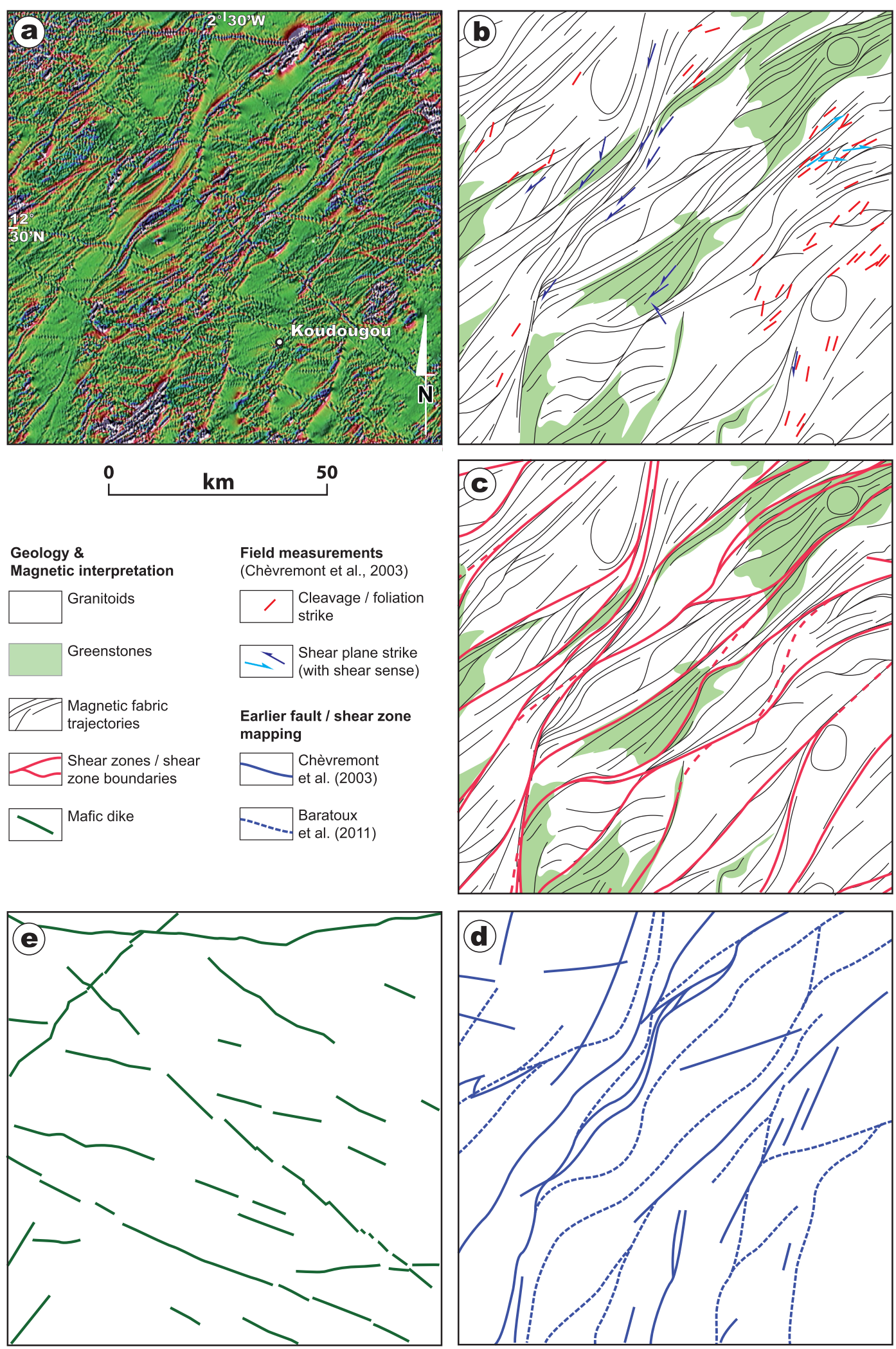

Fig. 2. Fabric/shear zone mapping protocol from aeromagnetic data and its validation illustrated for the Koudougou quadrangle (location on Fig. 1): (a) aeromagnetic map; (b) interpretative fabric trajectories with field measurements of Chèvremont et al. (2003); (c) interpretative shear zone pattern. The longest NNE-trending shear zone is the Ouahigouya shear zone (Fig. 3); (d) Faults/shear zones from earlier mapping works (Chèvremont et al., 2003; Baratoux et al., 2011); (e) interpretative pattern of the main mafic dikes. Geological contours are modified from Castaing et al. (2003). 


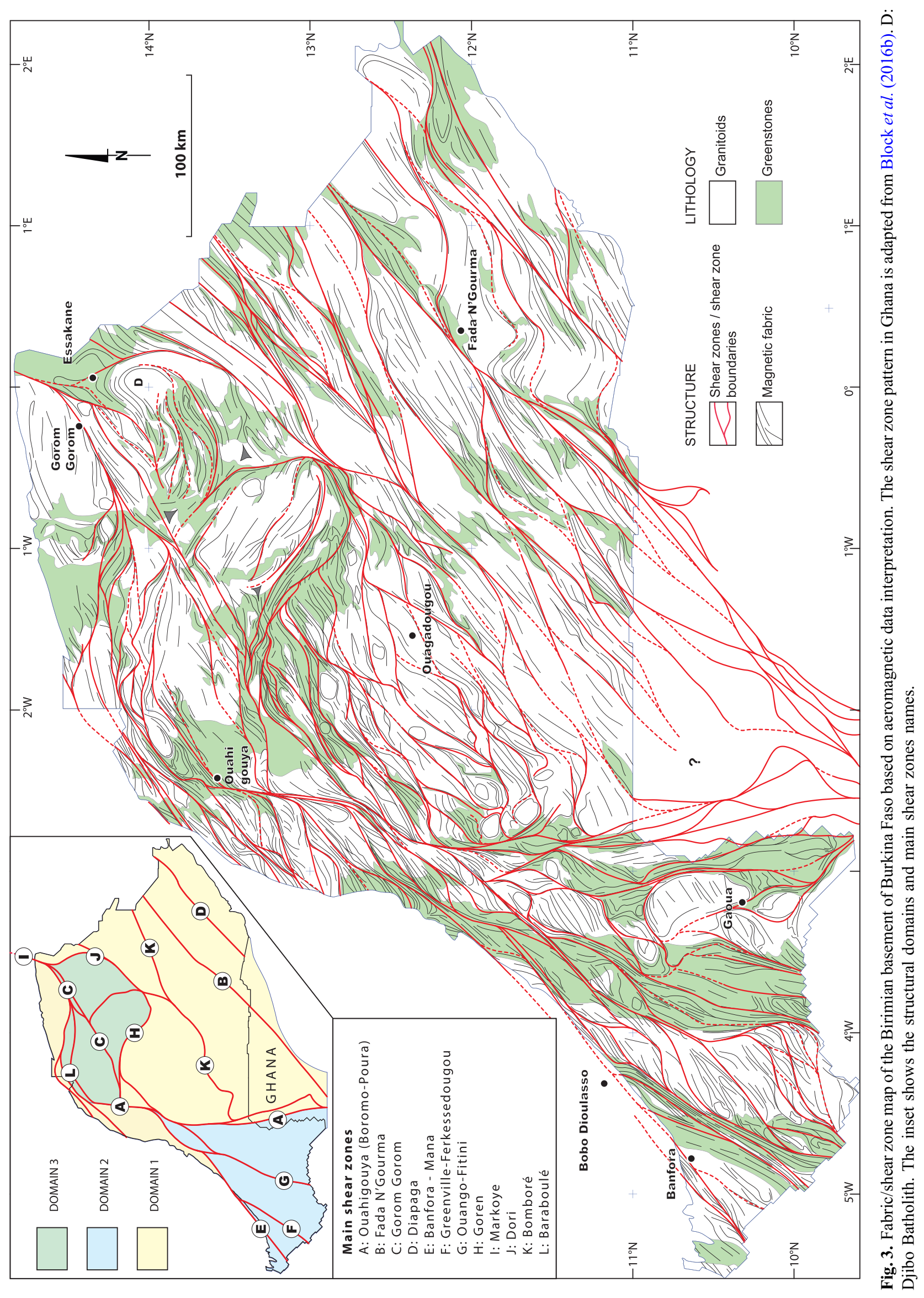




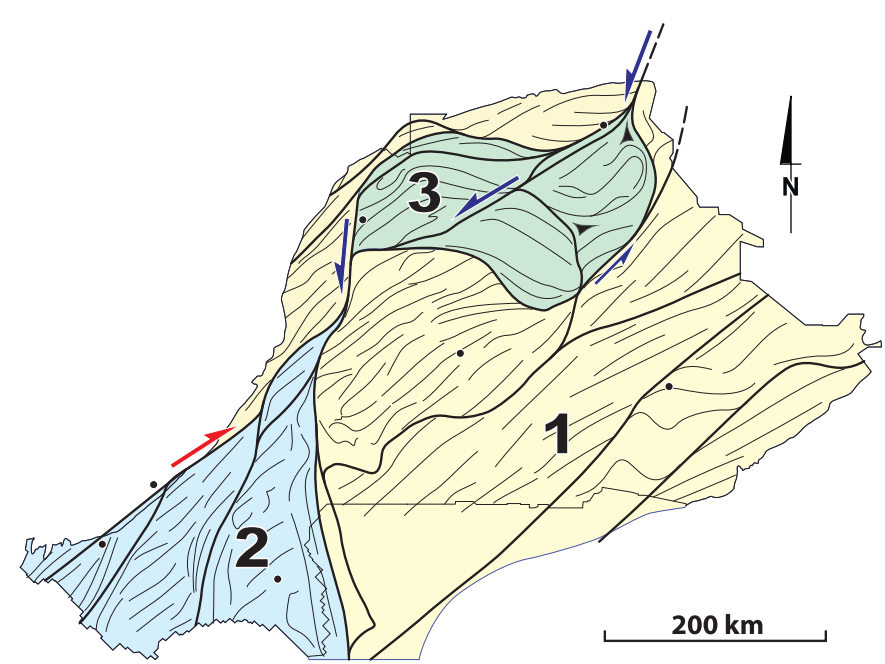

Fig. 4. Sketch structural model of the Eburnean basement of Burkina Faso and Northern Ghana. Colors and numbers refer to the structural domains discussed in the text. Localities of Fig. 3 are shown by dots.

Three structural domains are distinguished at the scale of the country (Fig. 4). Domain 1 occupies half of the exposed Eburnean crust (mostly over the southeastern part of the country; Fig. 4). It is characterized by dominantly rectilinear and parallel NE-trending fabrics and shear lenses that can be up to $200 \mathrm{~km}$-long and $100 \mathrm{~km}$-wide. Deformation was accompanied by the emplacement of batholiths elongate in the direction of the structural grain (Naba et al., 2004). A few straight shear zones of regional length $(>400 \mathrm{~km})$ are identified, the longest one being the Fada N'Gourma shear zone (Figs. 3 and 4). Perturbation of the foliation/shear zone trends South of Fada N'Gourma town is explained by back rotation of the fabrics (Harris, 2003) in between the Fada N'Gourma shear zone and the Diapaga shear zone (Fig. 3). This pattern, originally documented by Vegas et al. (2008), attests to a sinistral component of slip along those shear zones. Field observations in mining pits near the Ghana border confirms sinistral kinematics along the Fada N'Gourma shear zone (Woodman et al., 2016). Foliations and cleavages are very steep in both the granitoids and greenstones throughout domain 1 (e.g., Bonnard and Kagambega, 2003; Ouédraogo et al., 2003; Trinquard et al., 2003). Mineral-stretching lineations have variable plunges and may be very steep in the greenstones. Steep lineations in transcurrent shear zones (e.g., Fontaine et al., 2017) are indicative of transpression as the dominant deformation mode of domain 1. If the Fada N'Gourma shear zone appears to be sinistral in Burkina Faso, Block et al. (2016b) have shown that it was dextral in northern Ghana (Fig. 3). Sinistral shearing could be restrained to the SSW trending portion of the shear zone between Fada N'Gourma town and the border, as opposed to dextral along its remaining SW trending trace.

According to Block et al. (2016b), in situ U-Pb dating indicates that domain 1 crustal shortening and coeval lower crustal flow took place essentially between ca. 2140 and $2110 \mathrm{Ma}$ under high-grade metamorphic conditions, whereas strain localization along the strike-slip shear zones continued afterwards. The regional shear zone located between the Bomboré and Fada N'Gourma shear zones (Fig. 3) functioned at the time of emplacement of a $2140 \pm 7$ Ma dioritic body (in situ zircon U-Pb age; Fontaine et al., 2017), indicating that transcurrent tectonics started early in the preserved deformation history of domain 1 . Transcurrent tectonics would have lasted until after $2110 \mathrm{Ma}$ (end of high-grade metamorphism) to explain low-grade strike-slip strain localization $(<2100 \mathrm{Ma}$ ?).

At the scale of domain 1, fabric trajectories roughly bisect the angle between the two sets of shear zones delimitating the lenses, which is indicative of a component of pure shear achieved by the anastomosed shear zones network (i.e., bulk inhomogeneous pure shear; Gapais et al., 1987). The rectilinearity and parallelism of the fabric trajectories further attest to the intensity and homogeneity of the bulk strain. Shear sense inversion is required along curved lens-bounding shear zones throughout anastomosed shear networks. Kinematic complexities further arise at zipper junctions between shear zones (Hudleston, 1999; Platt and Passchier, 2016) within such networks. Therefore, the protracted convergence period $(>30 \mathrm{My}$ ) over which strain field 1 has evolved could result locally in apparently complex kinematic configurations due to shear zones interactions achieving the preservation of the kinematic coherency of the regional structural pattern. Interestingly, the NE-trending shear-fabric pattern could be explained locally on individual shear zones by a wide range of convergence obliquities through time and space, from wrench dominated dextral transpression responding to ENE-trending convergence, to wrench-dominated sinistral transpression (SSE-trending convergence), with intermediate configurations closed to pure shear dominated transpression (SEtrending convergence). In any case, the finite shear-zone/ fabric pattern of domain 1 argues for bulk NW-SE coaxial shortening and bulk NE-SW lateral stretching achieved by transpression.

Domain 2 occupies the southwestern and westernmost part of the map area (Fig. 4). It is characterized by an interlinked fabric and shear zone network, which is partitioned between:

- dominant $\mathrm{N}$ - to NNE trends within and along the boundaries of the greenstone belts;

- domain 1-type NE trends in intervening granitoid domains.

Overall, domain 2 displays a northward-converging pattern of regional shear zones that end up lining against the Ouahigouya shear zone (Figs. 1 and 3). This shear zone marks the eastern boundary of domain 2 and shows a consistent deflection pattern of foliation north of $12^{\circ} \mathrm{N}$, attesting to a component of finite sinistral slip (Fig. 3). Fabric deflection patterns along the NNE-trending shear zones are ambiguous, with dextrally asymmetrical trajectories, symmetrical trajectories (i.e., pure shear?) or - less commonly - sinistrally asymmetrical trajectories, sometimes along strike a same shear zone. NE-trending shear zones tend to show more consistently dextral asymmetrical deflection patterns. The density of those dextral NE-trending shear zones appears to increase northwestward up to the longest dextral shear zone of the domain (i.e., Banfora shear zone; Fig. 3). Baratoux et al. (2011) interpreted the regional shear zone pattern in domain 2 as due to a D2, wrench-dominated transpressional deformation event, which followed E-W shortening having led to the steep longitudinal foliation pattern of the greenstone belts. But the steep fabrics of greenstone belts must have functioned together 


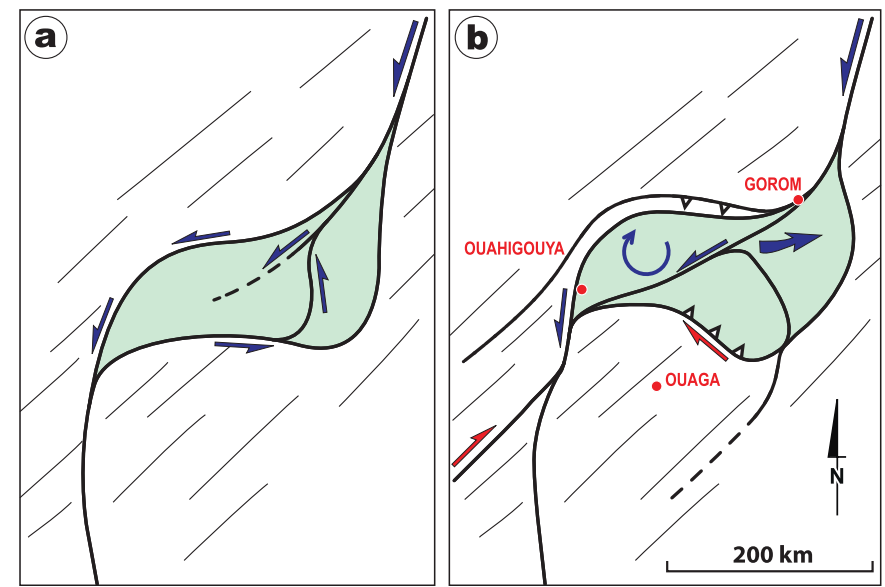

Fig. 5. Kinematic model for the growth of the Bouroum-Goren restraining bend in between the Markoye shear zone (to the East) and the Ouahigouya shear zones (to the west): (a) early bending stage; (b) final configuration. The model implies the closure of zipper junctions (Platt and Passchier, 2016) at both tips of the restraining bend.

with the shear zones and the granitoid fabrics for a protracted period to maintain the kinematic coherency of the anastomosed shear pattern between N-S greenstone corridors and intervening granitoids (Fig. 3). As documented by Lompo (2010), lineation pitches are variable on greenstone foliations (attesting to flattening strain) and are preferentially high (attesting to vertical stretch). Steep lineations are considered by Lompo (2010) to result from vertical tectonism due to diapirism. However, kinematic criteria near the granitegreenstone contacts that would substantiate such a model (Chardon et al., 1996) are still missing. The greenstone foliation and lineation pattern would instead be indicative of pure shear dominated transpression (Tikoff and Greene, 1997; Dewey et al., 1998). The fact that granitoids show preferentially shallowly plunging lineations outside pluton aureoles (Lompo, 2010; Baratoux et al., 2011) argues for strain partitioning in the anastomosed shear network between pure shear dominated transpression in the greenstone belts and strike-slip dominated transpression in the granitoids. U-Pb geochronology indicates that the domain 2 strain pattern was functional after ca. $2160 \mathrm{Ma}$ (oldest TTG and plutons interpreted to have emplaced during acquisition of the steep $\mathrm{N}$ - trending fabric) and until after ca. $2100 \mathrm{Ma}$ (latest potassic plutons affected by mylonitic shearing; Baratoux et al., 2011). There is therefore a significant time overlap ( $>40 \mathrm{My}$ ?) in the deformation history of domains 1 and 2 .

Domain 3 occupies the north-central part of the country (Fig. 4) and corresponds to an area of domain 1 where the regional NE structural trend of the fabrics, shear zones and greenstone belts is perturbed. The domain is a composite, lazy $\mathrm{Z}$ shaped mega shear lens. It is divided in two by the Gorom Gorom shear zone, which is also the symmetry axis of the mega shear lens and connects the sinistral Markoye shear zone (Tshibubudze and Hein, 2013), in the NE, to the northern sinistral portion of the Ouahigouya shear zone, in the SW (Fig. 3). The mega shear lens is interpreted as a restraining bend developed in between the two shear zones (Fig. 5) and is called hereafter the Bouroum-Goren restraining bend.
This interpretation accounts for the map scale bend made by the Goren greenstone belt as the result of clockwise rotation concomitant with sinistral slip of the northward propagating tip of the Ouahigouya shear zone (Fig. 5). Rotation and slip produced the abutment pattern of domain 1-related NEtrending foliations against NE trends of the southwestern envelop of the restraining bend NNE of Ouagadougou (against the Goren shear zone; Figs. 3 and 5). This abutment pattern earlier documented by Hein et al. (2004) is here interpreted to result from dominantly dextral transpression along the Goren shear zone as a consequence of growth and rotation of the restraining bend (Fig. 5). Dextral shearing combined with NEside up reverse slip documented by Hein (2010) along that shear zone is therefore consistent with the restraining bend model (Fig. 5). The model further accounts for NNE-directed thrusting combined with sinistral strike-slip documented by Nikiema (1992) and Debat et al. (2003) along the northern margin of the restraining bend (Baraboulé shear zone; Fig. 3) in a context symmetrical to that of the Goren shear zone (Figs. 3 and 5). Reverse shearing along that margin post-dates the amphibolite facies metamorphic aureole of the plutons (Debat et al., 2003). This, together with the abutment pattern at the southwestern margin of the bend, shows that the BouroumGoren bend is a late tectonic feature that has grown at the expense of domain 1 .

\subsection{Kinematic interpretation}

The Eburnean deformation pattern of Burkina Faso (Figs. 3 and 4) is interpreted to result from the interferences between the strain field typified by domain 1 and regional-scale shear zones trending N to NNE. Strain field 1 developed throughout the country. It was achieved by steep and parallel foliations trending NE combined with a regionally anastomosed network of transpressive shear zones, which recorded bulk inhomogeneous shortening on a regional scale. The first type of perturbation in that strain field occurs in domain 2, where $\mathrm{N}$ - to NNE-trending shear systems alternate with corridors of NEtrending, domain 1-type fabrics (Fig. 4). This interference results from the activation of the northward-convergent fan pattern of regional-scale shear zones (i.e., Fig. 1) onto strain field 1. The second type of perturbation was produced by the development of the Bouroum-Goren restraining bend between the northern tip of the regional-scale fan shear zone pattern of domain 2 and the Markoye shear zone (Figs. 3 and 5). Domain 1 would therefore contain the oldest Eburnean pervasive fabrics preserved regionally. However, perturbation of strain field 1 instead of its regionally pervasive overprint by $\mathrm{N}$ - to NNE trending domain 2-type shears argues for the rejuvenation of the NE-trending structural grain during the development of patterns 2 and 3 despite potential change(s) in the tectonic boundary conditions the later might have been triggered by. This could further explain local kinematic complexities expected inside domain 1 .

\section{Craton-scale deformation pattern}

\subsection{Fabric and shear zone patterns}

We produced a new fabric/shear zone map of the sWAC based on fabric trajectories derived from foliation/cleavage 

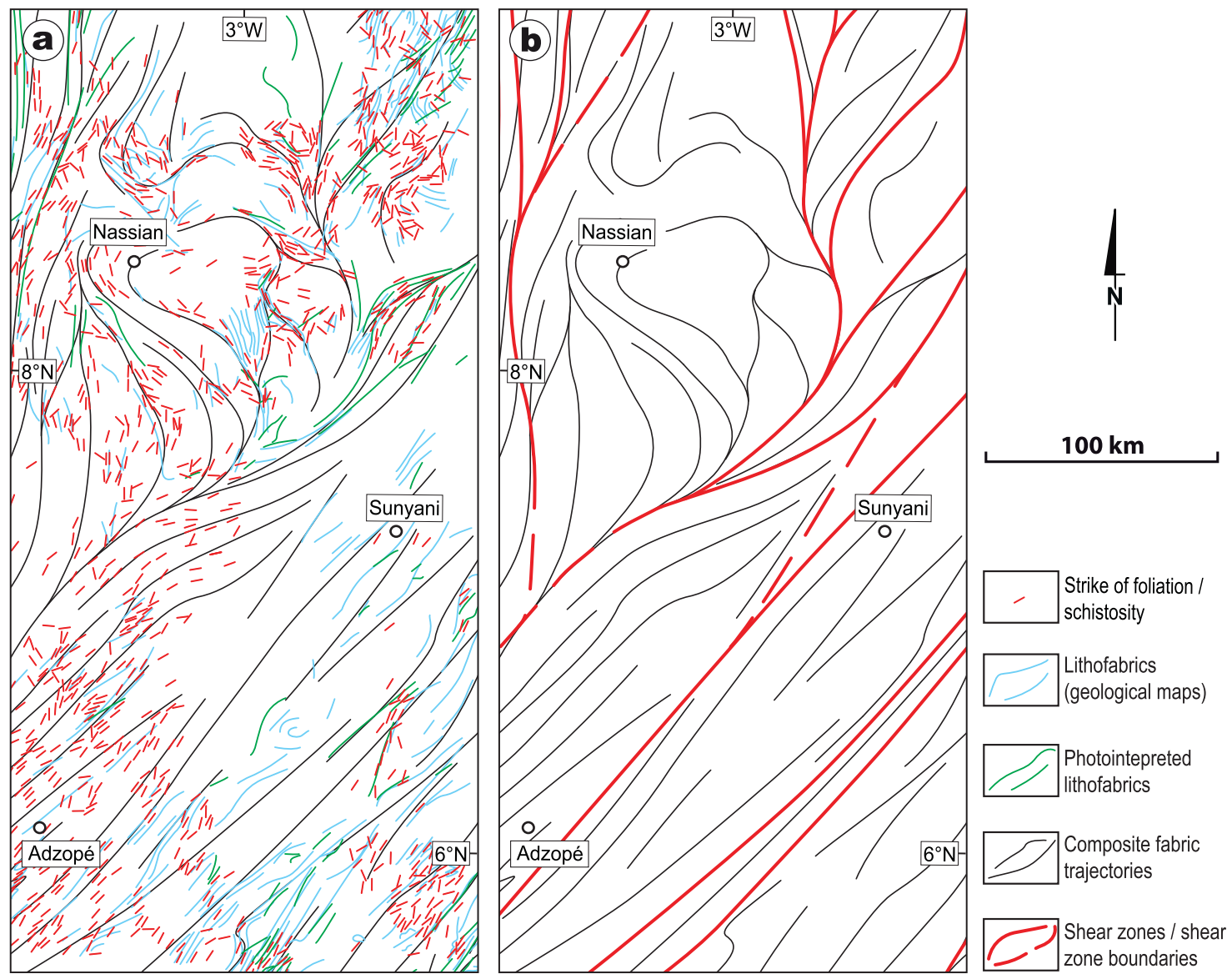

Fig. 6. Fabric/shear zones mapping protocol at the scale of the southern West African craton (Fig. 7a) illustrated on the Comoé area in the Côte d'Ivoire - Ghana border region (location on Fig. 1): (a) fabric trajectories drawn after foliation measurements, lithological fabrics from geological maps and photointerpreted fabrics; (b) interpretative shear zone pattern superimposed on the fabric trajectories. Source maps: Bureau de Recherches Géologiques et Minières (1963), Eisenlohr (1989), Delor et al. (1992, 1995), Adou et al. (1995), Siméon et al. (1995), Zeade et al. (1995), Griffis Consulting and Exploration Services, Watson Geophysics (1998), Zitzmann (1998), Ghana Geological Survey (2008a, 2008b, 2008c).

data and lithological fabrics retrieved from geological maps and photointerpretation using the GoogleEarth ${ }^{\mathrm{TM}}$ software (Figs. 6 and 7a). The main shear zones were drawn from the fabric trajectories the same way shear zone were derived from magnetic fabrics in the case of Burkina Faso (Figs. 2 and 6).

Based on the craton-scale shear zone patterns (Fig. 7a), five deformation provinces are defined (Fig. 7b). The Burghana province has consistent NE-trending transpressive fabrics and shear zones (Fig. 7b). The Ivorian province is defined by a lozenge-shaped shear zone pattern covering most of Côte d'Ivoire (Fig. 7b). It consists in stacked, N- to NNE- trending shear lenses that end up in the Bouroum-Goren restraining bend in Burkina Faso (domains 2 and 3 in Figs. 4 and 7b). The Archean province is affected by a highly curved, eastwardconvex shear zone pattern (Fig. 7b). The southern flank of that arch is made of dominantly dextral shears and the northern flank by a sinistral shear system (Egal et al., 2002; Fig. 7b). The hybrid province (Fig. 7b) has undergone mostly Eburnean high-grade metamorphism (Pitra et al., 2010) and consists of reworked Archean crust and hybrid Archean-Birimian crust (Kouamelan et al., 1997, 2018). It is affected by ENE-trending shear lenses pinched south of the Archean province against the
Ivorian province (Fig. 7b). Two shear lenses of that province (mostly Birimian) may be mapped north of the contact between the Archean and Ivorian provinces (Caby et al., 2000; Thiéblemont, 2016; Fig. 7b). The Guineo-Malian province corresponds to a northward fanning shear zone pattern in between the Archean and Ivorian provinces (Fig. 7b).

\subsection{Kinematic interpretation}

The early NE-trending regional fabrics are inferred to have affected at least the Ivorian province in addition of the Burghana province (K. Traoré, unpublished data; see also Fig. 4). Development of the Ivorian shear pattern was due to the northeastward movement of the Kénéma-Man domain and dextral slip along a wide NE-trending deformation belt belonging to the Burghana province (Figs. 7 and 8). This belt is called hereafter the Burghana-Transamazonian (B-T) mega shear because it has to extend southwestward into the Guiana shield where the South American counterpart of the Eburnean orogeny is called Transamazonian (e.g., Ledru et al., 1994; Vanderhaeghe et al., 1998). The B-T mega shear marks the southeastern contact of the orogen with an Archean buttress 

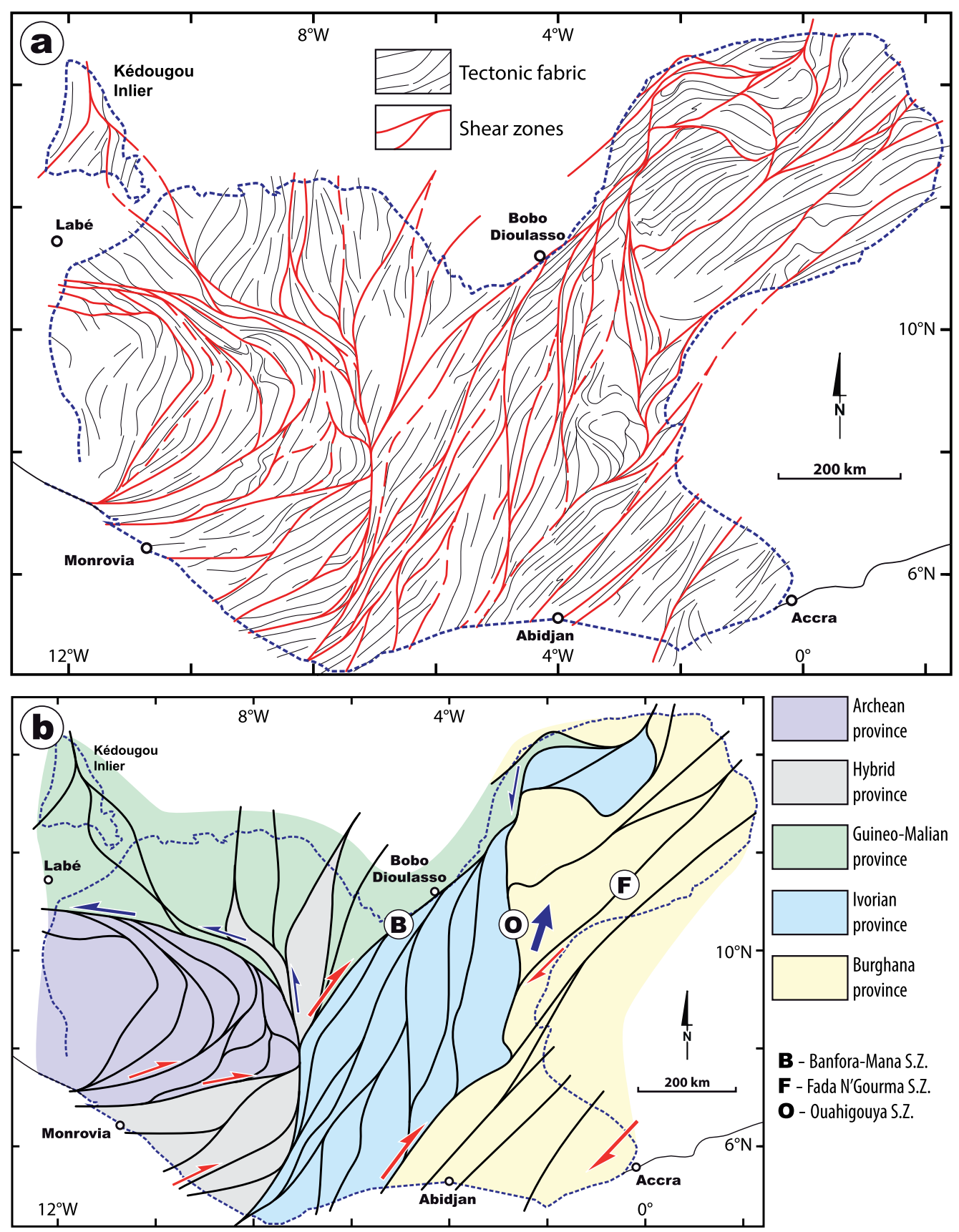

Fig. 7. (a) Fabric/shear zone map of the southern West African craton after a compilation of fabric data from published geological maps and photointerpretation (Fig. 6). This new map allows refining and complementing the shear zone/fault pattern of Milési et al. (1989) and Thiéblemont (2016) (see Fig. 1 for comparison); (b) deformation provinces map of the southern West African craton based on (a). The boundary between the Guineo-Malian and the Burghana provinces in northwestern Burkina Faso (NE of Bobo Dioulasso) is not well-constrained.

(Feybesse and Milesi, 1994; Ledru et al., 1994; Fig. 8) that could be the Congo craton at the time (e.g., Lompo, 2009). Structural studies of the B-T mega shear attest to a protracted and locally complex deformation history (Perrouty et al., 2012; McFarlane et al., 2019 and references therein). But the systematic interference between steep reverse and strike-slip shearing (Ledru et al., 1994; Feybesse et al., 2006) argues for deformation partitioning through time and space during longlasting or repeated transpression (Eisenlohr and Hirdes, 1992) comparable to domain 1 of Burkina Faso (Figs. 1 and 4). Strain analysis of a $80-\mathrm{km}$ wide strip of the northwestern B-T mega shear suggests $>400 \mathrm{~km}$ of dextral of simple shear (Jessell et al., 2012), which is consistent with the deflection pattern of fabrics and shear zones of the Ivorian province towards that contact and the net dextral slip suggested by our reconstruction (Figs. 6-Figs. 6, 7a and 8).

Collision with the Kénéma-Man domain drove the growth of the N-S strike slip duplexes of the Ivorian 


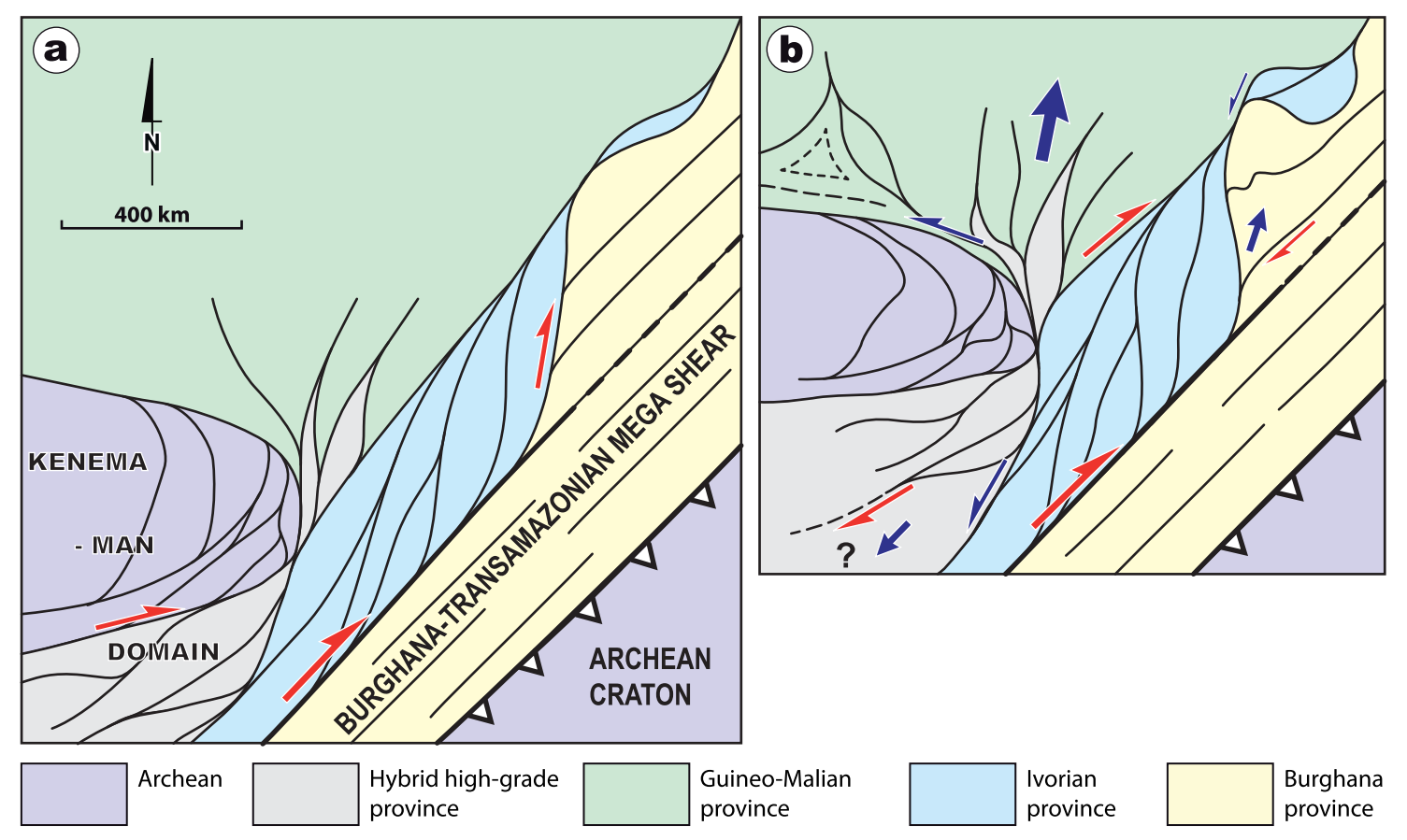

Fig. 8. Kinematic model for the late development stages of the Eburnean orogen of the southern West African craton. The BurghanaTransamazonian mega shear and the adjoining Archean craton have been taken as stationary in this reconstruction: (a) early shortening of the orogen by the Kénéma-Man domain against the Burghana-Transamazonian mega shear: nucleation of the Ivorian lozenge shear zone pattern; (b) final configuration: shortening of the Ivorian shear lozenge and northward extrusion of the Guineo-Malian domain; southwestward extrusion (?) of the high-grade hybrid crust of the Kénéma-Man domain.

province while the Burghana province maintained its NEtrending structural grain (e.g., domain 1 versus domain 2 in Burkina Faso; Fig. 4). Sinistral kinematics of the N-trending portions of the Ivorian province shear zones (e.g., Mortimer, 1992; Vidal et al., 1996; Gasquet et al., 2003; Grenholm et al., 2019) accommodated conjugate slip with respect to the B-T mega shear and the Banfora-Mana shear zone (Fig. 7b), contributing to shortening and northeastward extrusion of the province (Fig. 8). That extrusion was ultimately absorbed in Burkina Faso by escape in between the Fada N'Gourma and Ouahigouya shear zones (see also Grenholm et al., 2019) and formation of the sinistral Bouroum-Goren restraining bend at the tip of the Ivorian lozenge (Figs. 7 and 8).

Over-bending of the arched shear pattern in the Archean province is suggested during collision with the Birimian crust (Fig. 8), resulting in an apparent orocline. Bending was associated with transpressional crustal thickening and highgrade metamorphism (Pitra et al., 2010) in the southeastern Kénéma-Man domain, while voluminous magmatism and sinistral transpression took place along the northern flank of the bend (Égal et al., 2002; Eglinger et al., 2017). Exhumation of high-grade terrains in the Archean and hybrid provinces is likely linked to transpressional thickening and/or lateral escape on both sides of the contact zone between the Archean and Ivorian provinces (Fig. 8). The Guineo-Malian province developed a shear zone pattern mostly indicative of northward extrusion from the collision zone between the Archean and Ivorian provinces (e.g., Feybesse and Milesi, 1994; Fig. 8). The kinematic reconstruction implies that significant N-S convergence $(>200 \mathrm{~km})$ must be absorbed at the northern margin of the Kénéma-Man domain as a consequence of slip along the B-T mega shear (Fig. 8). This could have required subduction to have taken place along this boundary to absorb that convergence (see Eglinger et al., 2017 and Wane et al., 2018 for recent petro-geodynamical scenarios).

The deformation of each Birimian province was mostly controlled by its position in the orogen. The B-T mega shear remained a rectilinear boundary of the orogen. The rest of the Burghana province maintained its dominant NE-trending Eoeburnean tectonic grain during collision with the Kénéma-Man domain because it was the most distant from the collision zone (Figs. 7 and 8). A shift in peak age felsic plutonic activity, from older to younger, is documented across the Ouahigouya shear zone (Block et al., 2016a) and the Banfora-Mana shear zone (Parra-Avila et al., 2017) (Fig. 7b). This also suggests stiffness contrasts among the Burghana (outside the B-T mega shear), Ivorian and Guineo-Malian provinces that could also explain their contrasted mechanical/kinematic behavior during collision. The sWAC finite strain pattern was acquired mostly from ca. $2140 \mathrm{Ma}$ onward. Regional deformation, strain localization on shear zones and plutonism lasted until ca. $2060 \mathrm{Ma}$ with an overall younging age in plutonism towards the collisional contact with the Kénéma-Man domain (Grenholm et al., 2019).

\section{Significance of large-scale shear zone patterns: a discussion}

Although the regional and craton-scale strain and shear zone patterns of the sWAC evolved over tens of millions of 

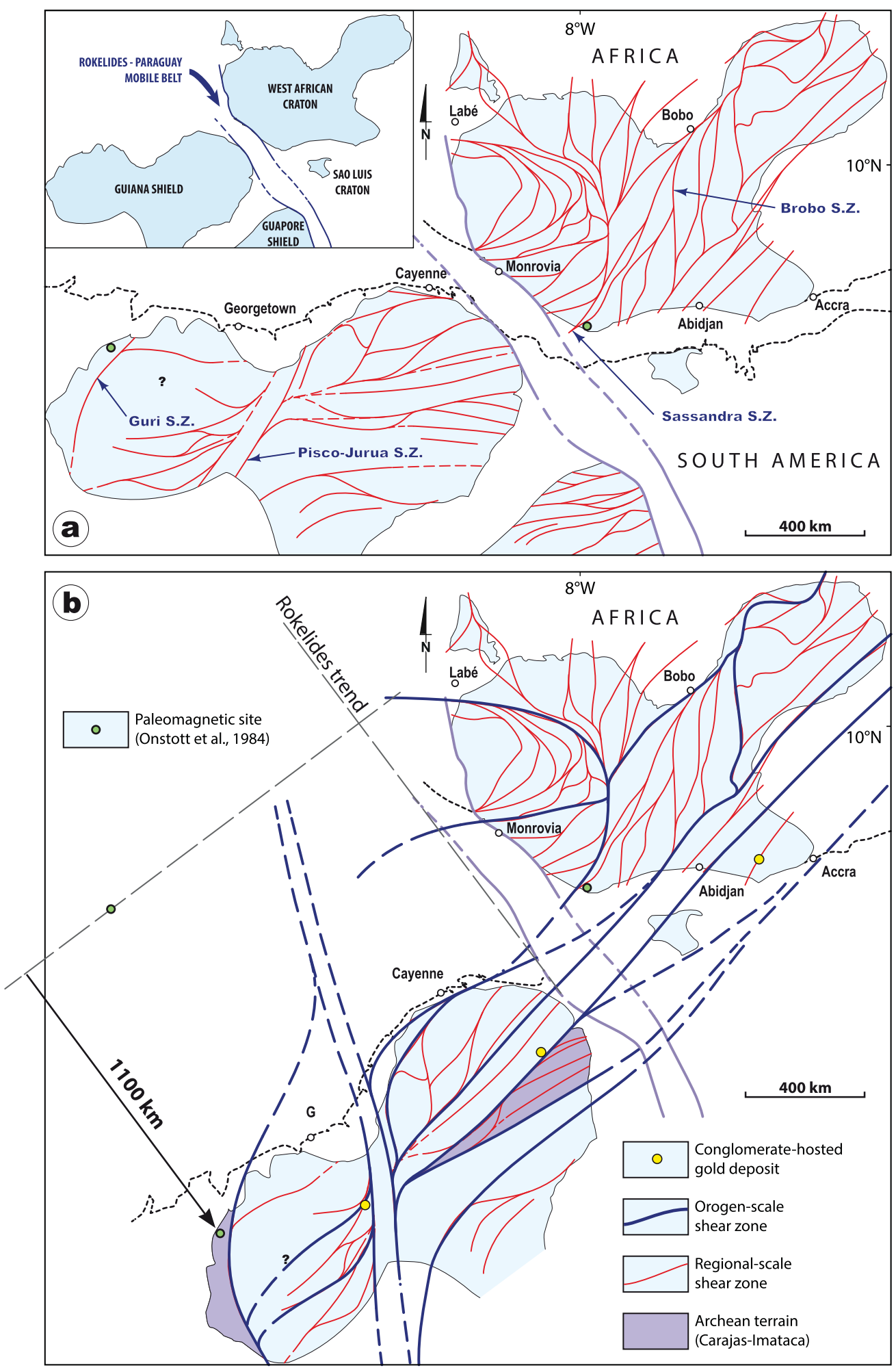

Fig. 9. Transatlantic Eburnean-Transamazonian correlation (in today's Africa reference frame): (a) configuration at the end of the Paleozoic based on the Africa - South America pre-rift fit of the Equatorial Atlantic Ocean of Ye et al. (2017). The shear zone pattern in South America has been compiled mostly after Gibbs and Baron (1993), Delor et al. (2003b) and Cordani et al. (2006). The inset shows the relative position of cratons and the Panafrican mobile belt; (b) reconstruction of the Eburnean-Transamazonian orogen before Neoproterozoic formation of the Rokelides - Paraguay mobile belt (see text for further explanation). The reconstruction implies chisel-like closure of a Panafrican ocean accompanying clockwise rotation of the Guiana shield and limited $(<300 \mathrm{~km})$ right-lateral movement along the mobile belt during Panafrican collision. Chisel-like closure of a "Rokelides ocean" would explain why a suture zone is imaged along the NNE-trending segment of the orogen (South of Labé; Ponsard et al., 1988), whereas such a suture is disputed further to the SE (Monrovia area; Williams and Culver, 1988). 
years, their geometrical interpretation provides first-order kinematic constraints on the evolution of the orogenic system. The sWAC is imprinted by bulk inhomogeneous transpressional shortening recorded by anastomosed networks of steep shear zones and steep regional planar fabrics. Anastomosed shears define shear lenses up to ca. 150 and $300 \mathrm{~km}$ in length on the regional and craton-scale, respectively. The connectivity of the shear networks implies limited horizontal and vertical offsets of individual shears. The map view conjugate and mostly symmetrical character of the shear lenses show that lateral horizontal stretching with a coaxial component of deformation is significant. Such regional strain patterns are indicative of the homogeneous shortening of a soft orogenic lithosphere lacking a stiff mantle layer, which would be typical of Precambrian accretionary orogens (Choukroune et al., 1995; Gapais et al., 2005; Cagnard et al., 2006a, 2006b; Cruden et al., 2006; Chardon et al., 2009; Harris and Bédard, 2014). Instead of large localized displacements, shear zone networks accommodated bulk deformation and absorbed kinematic incoherencies generated by instabilities or heterogeneities in the crustal flow pattern. Only a few very long $(>300 \mathrm{~km})$ rectilinear shear zones such as the B-T mega shear may have accommodated displacement of prime tectonic importance between deformation provinces (Fig. 8).

\subsection{Refining the shear zone patterns: kinematic consequences}

Mapping of tectonic fabrics has allowed refining the regional shear zone patterns. The kinematic information retrieved from those patterns may be overlooked by conventional geological mapping or local structural geology, as illustrated on the Burkina Faso case example. Our map (Figs. 3 and 7) indicates that the branches of the Banfora-Mana shear system (Fig. 7b) do not terminate in central Burkina Faso as shown on Figure 1 but merge and branch onto the Ouahigouya shear zone (see Castaing et al. (2003), Figs. 3 and $7 b$ ). Instead of being the latest (D3) tectonic features in the sWAC as argued originally by Milési et al. (1989), those dextral shear zones have coexisted with N-S, dominantly sinistral conjugates in the interlinked Ivorian shear lozenge (Figs. 1 and 7). Those dextral shears could not therefore have rotated the Goren greenstone belt and shear zone (Fig. 3) from N-S to NW-SE as suggested by Feybesse et al. (1990). Hein (2010) interpreted dextral transpression in the Goren shear zone (Figs. 3 and 5) as due to an Eoeburnean (i.e., "Tangaean") regional phase of SW-vergent reverse faulting (Tshibubudze et al., 2009). However, the abutment pattern of domain 1 fabrics against the Goren shear zone (Figs. 3-5) indicates that domain 1 NE-trending fabrics had to preexist the shear zone (and acquisition of the NW Goren trend). The Goren shear zone cannot therefore be an Eoeburnean feature. The sinistral restraining bend model therefore appears to better account for the regional finite strain pattern and field kinematic observations made in Central Burkina Faso. For Feybesse et al. (1990), steep tight to isoclinal folds in greenstone belts were originally produced by Eoeburnean low-angle thrust tectonics. Still, if earliest pervasive fabrics of regional extent in Burkina Faso should preferentially be preserved in domain 1 (Fig. 4), evidence for an even earlier (Eoeburnean) kinematically distinct regional deformation - if any - would be elusive given the imprint of long-lasting transpression along the NE structural grain.

\subsection{The deformation phase approach}

The present work suggests that the deformation phase approach that would not take into account large-scale (100$1000 \mathrm{~km}$ ) structural patterns could be misleading, as apparently complex kinematic configurations arise from interactions among shear zones (e.g., Fig. 5) that would classically be systematized as a series of deformation events. But more generally, the phase approach would be misleading for four reasons. The first reason is that even a single progressive simple shearing episode can generate the superimposition of apparently incompatible classes of schistosities, veins and folds that rotate differentially during deformation (Brun and Choukroune, 1981) as well as conjugate shear zone patterns (Harris and Cobbold, 1985). Simple shearing also generates C' shears oblique on the fabrics tracking the bulk shear direction (Berthé et al., 1979). In some cases, the phase approach would lead to interpret outcrop- or map-scale C' shears as resulting from a deformation event younger than, and kinematically unrelated to, the shear deformation that actually produced them. C' shears, as syn-cooling features, are indeed commonly brittle-ductile and contrast with the simple shearing fabrics they affect. Such a coexistence of brittle and ductile structures during progressive deformation tends to be ignored in the phase approach. The second reason to challenge the phase structural approach is the ubiquitous three-dimensional strain partitioning between strike-slip shearing, reverse shearing and planar and linear fabrics that coexist in transpressional contexts (Hudleston et al., 1988; Tikoff and Teyssier, 1994; Gapais et al., 2005, Gapais, 2018; Harris and Bédard, 2014). The third reason is that by favoring a local phase approach, one tends not to consider the spatial kinematic diversity of localities as part of a progressive/bulk deformation pattern that would be coherent on a regional scale (examples of regional kinematic integration are provided, for instance, by Martelat et al., 2000; Gapais et al., 2005; Harris and Bédard, 2014; Cochelin et al., 2017). The last and fourth reason is that one must consider fabrics and shear zones rotation and the zipping/ unzipping of shear zones (Platt and Passchier, 2016) during the deformation history of regional structures (e.g., Bouroum-Goren bend; Fig. 5). Those processes would commonly lead to shear sense inversion along shear zones through time and/or to spatially contradictory shear senses along individual shear zones at a given time, notwithstanding the fact that the pure shear component of transpression tends to generate conjugate strike-slip shears in individual shear zones.

Dynamic analysis, on which the phase approach is implicitly based, would therefore be of limited value (Tikoff and Wojtal, 1999; Gapais et al., 2000) to infer shortening directions within shear systems such as that of the sWAC (see Grenholm et al., 2019 for a compilation of such directions). The concept of episodic Eburnean orogeny (Block et al., 2016b; McFarlane et al., 2019) derived from such analyses relies on unnecessarily complex and untestable deformation histories, which are based on 5/7-phase scenarios ignoring partitioning of protracted convergent deformation that led to the finite strain pattern. Only 


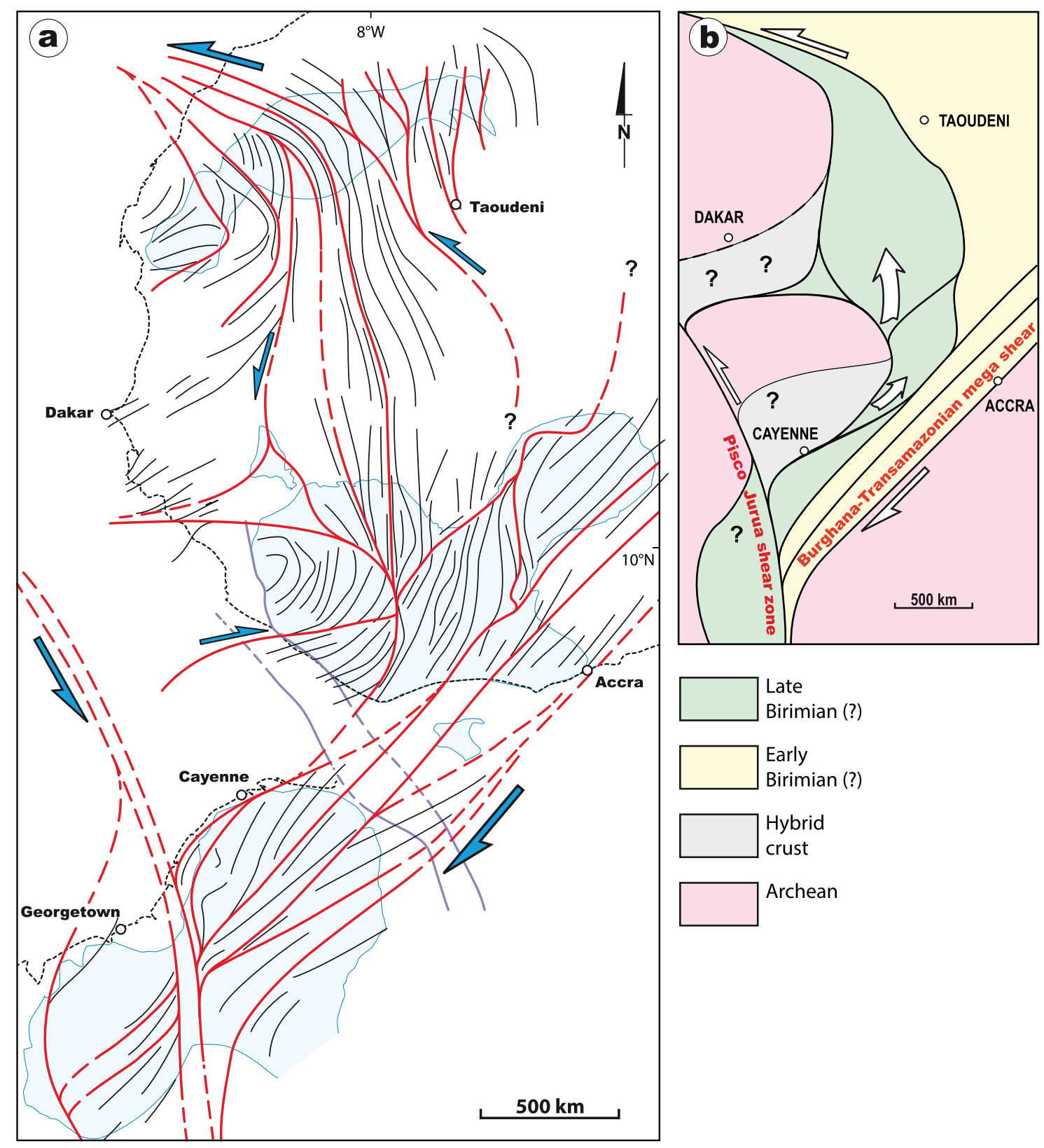

Fig. 10. (a) Structural pattern of the Eburnean-Transamazonian orogen. Fabrics are in black and the shear zones in red. Fabrics in Africa (adapted from Jessell et al., 2016) derive from joint interpretation of medium-wavelength $(>30 \mathrm{~km})$ Bouger gravity anomaly and magnetic data in exposed and buried Archean and Birimian crust. Shear zones in the Reguibat shield (northern outcrop of the West African craton) are adapted from Milési et al. (2010); (b) corresponding tectonic model (same frame as Fig. 10a).

structural artifacts that would definitely not fit into the finite strain pattern could provide clues on an early tectonic history but the distortion and rotation they must have undergone would be difficult to take into account.

\subsection{Tectonic significance of the shear zone patterns}

In map view (e.g., Fig. 7a), fabrics and shear zones track the horizontal component of finite elongation and the lines of no finite elongation, respectively (Gapais et al., 1987, 1991).
Thus, they have no simple relationships to the degree of slip partitioning or shear sense along shear zones or to a far-field convergence vector. NW-trending shortening inferred from local data over the Ivorian and Burghana provinces (Grenholm et al., 2019; Fig. 7b) accounts for the fairly consistent NE trend of the fabrics (Fig. 7a). This fabric trend actually records the pure shear component of transpression parallel to the B-T mega shear bounding the orogen (e.g., Fig. 10a), not actual convergence with the southeastern craton. Relative displacement between the Kénéma-Man domain and the southeastern craton would be E- or NE-trending (e.g., Fig. 8), instead of 
NW-trending as deduced as normal to the NE-trending fabrics (Grenholm et al., 2019). Therefore, strain partitioning inside and at the margins of the orogen prevents retrieval of convergent plate kinematics and slip sense on a shear zone has no simple relationship to the relative convergence vector. In other words, the shear zone patterns are indicative of the flow regimes inside the orogen, which are primarily imposed by the shape of the stiff converging provinces to the soft Birimian lithosphere.

\subsection{Eburnean orogenic processes}

Syn-convergence extensional exhumation of partially molten lower crust (e.g., Block et al., 2015, 2016b; McFarlane et al., 2019) took place at a low angle to the regional structural trends in the sWAC, attesting to the involvement of the lower crust in the lateral flow process (e.g., Chardon et al., 2011). Exhumation was also permitted despite convergence in sites kinematically favorable for transtensional exhumation to take place (e.g., Cochelin et al., 2017) such as the junction of regional shear zones (e.g., between the Ouahigouya and Fada N'Gourma shear zones; Block et al., 2016b; Fig. 7b). Lateral flow is interpreted to have compensated part of the crustal thickening of the soft Birimian crust.

Whether early Eoeburnean deformation could proceed by low-angle thrust stacking of mafic crustal slices and supracrustals or already by steep transpression remains an open question. The first tectonic process could explain early HP-LT apparent geotherms recorded by greenstones (Ganne et al., 2012, 2014; Block et al., 2015). But transpressional burial of supracrustals by pop-down tectonics (Gapais et al., 2014; Gapais, 2018) and subsequent upward extrusion (Thompson et al., 1997) might as well and would be consistent with early and long-lasting transpression leading to the sWAC finite structural pattern. If PTt paths of Birimian supracrustals may be "reminiscent of modern collisional orogens" (McFarlane et al., 2019), the pervasive transpressive structural pattern of the Eburnean orogen does not compare at all the thrust or gravitational collapse patterns of Variscan or Alpine collision belts.

\section{Configuration of the Eburnean- Transamazonian orogen}

The updated shear zone map of the sWAC (Fig. 7a) prompted a new reconstruction of the Eburnean-Transamazonian orogen between the sWAC and the Guiana shied across the Equatorial Atlantic Ocean (Fig. 9). Existing reconstructions (e.g., Feybesse and Milesi, 1994; Ledru et al., 1994) were based on a pre-rift fit of Africa and South America. They did not consider the Neoproterozoic relative displacement between the two cratons (Fig. 9a) suggested by paleomagnetic data. Onstott and Hargraves (1981) and Onstott et al. (1984) indeed computed ca. $1000 \mathrm{~km}$ of sinistral translation of the cratons parallel to the Panafrican Rokelides-Paraguay mobile belt to allow for both aligning the Guri and Sassandra shear zones and merging the discordant paleopoles from the two Birimian localities shown on Figure 9a. Later reconstruction of Nomade et al. (2003) connected the Guri shear zone to the Sassandra shear zone and the Pisco-Jurua shear zones to the Brobo shear zone (Fig. 9a). But this reconstruction generated incoherencies in the transatlantic Eburnean strain pattern (Nomade et al., 2003) and was incompatible with the geometry of the Panafrican mobile belt. Indeed, the Guiana shield would be transected in the middle by the mobile belt in this reconstruction, whereas it must have lied southwest of the belt before the Neoproterozoic. Furthermore, the Brobo shear zone, which is cut by the B-T mega shear (Figs. 8 and 9), could not extend southward into the Pisco-Jurua shear zone and its flanking granulite belt that form the latest $(<2.05 \mathrm{Ga})$ structure cutting the entire Guiana shield (Delor et al., 2003a; Kroonenberg et al., 2016).

The new reconstruction (Fig. 9b) is based on a recent prerift continental fit taking into account syn-rift extensional deformation of the continental margins (Ye et al., 2017) and a structural correlation that allows aligning the longest and most rectilinear shear corridor in the Guiana shield with the B-T mega shear. This shear corridor is flanked to the SE by (or hosts) an Archean Carajas-Imataca unit (e.g., Delor et al., 2003b; Cordani et al., 2006; Fig. 10b), in agreement with the B-T mega shear having interacted with an Archean craton located to the SE (Fig. 8). Our reconstruction would also be consistent with the B-T mega shear being the sole host of conglomerate-hosted gold deposits (Tarkwa-type; e.g., Frimmel, 2014) in the orogen (Fig. 9b). The restoration requires $37^{\circ}$ anticlockwise rotation of the Guiana shied, $270 \mathrm{~km}$ of net sinistral slip along the mobile belt, and implies $1080 \mathrm{~km}$ of sinistral offset of the paleomagnetic sites of Onstott and Hargraves (1981) parallel to the mobile belt (Fig. 9b). The proposed reconstruction therefore accounts for:

- an updated structural-geological Eburnean-Transamazonian correlation;

- paleoproterozoic paleomagnetic data;

- an updated Equatorial pre-rift fit of Africa and South America.

The new reconstruction was used to compile a structural map at the scale of the West African craton and the Guiana shield (Fig. 10a) on the basis of the present work and the geophysical data compiled and interpreted by Jessell et al. (2016). This map shows that the western portion of the Eburnean-Transamazonian orogen is arched as a result of indentation by two Archean provinces (Fig. 10a). The orogen is pinched in the South in between the B-T mega shear and the Pisco-Jurua shear zone, the later having acted as a late structure necking the orogen (Figs. 9 and 10). Symmetrical pinching is suggested at the northern termination of the arch although later than in the sWAC, as suggested by geochronological data (Grenholm et al., 2019). The new orogen-scale model would explain northward escape/extrusion of the Guineo-Malian crust into the central part of the orogenic arch where it would be the widest (Figs. 8 and 10b). Continuation of the orogen south of the map area of Figure 10 as an Eburnean megaboudin is not precluded.

\section{Conclusions}

Regional-scale (100-1000 km-long) shear zones of the Eburnean accretionary orogen are arranged as a transpressional 
anastomosed network that accommodated long-lasting distributed shortening and lateral flow of the hot Birimian lithosphere between the converging Kénéma-Man and Congo Archean provinces. Interference patterns in the shear network were due to interactions among shear zones and three-dimensional partitioning of progressive transpression that absorbed heterogeneities in the orogenic flow and maintained the network connectivity. The Eburnean example shows that mapping of finite strain and shear zone patterns from tectonic fabric trajectories is a valuable tool to infer orogen-scale kinematics and calls for caution in using local phase approach in structural analysis without considering the "bigger picture". A new structural correlation between the West African craton and the Guiana shield provides a tectonic framework for the studied shear patterns at the scale of the Eburnean-Transamazonian orogen.

\section{Supplementary material}

Supplementary file. Structure and gold deposits of the Birimian basement of Burkina Faso.

The Supplementary Material is available at https:/www.bsgfjournal.org/10.1051/bsgf/2020001/olm.

Acknowledgments. This work was supported by IRD (JEAI FasoLith). Aeromagnetic images were provided by the BUMIGEB (Bureau des Mines et de la Géologie du Burkina). We thank Augustin Sebgo for his help in the course of the study. We also thank Mark Jessell, Lenka Baratoux and Stéphane Perrouty for sharing geological maps of the sWAC. Reviews by Nicolas Thébaud and an anonymous referee helped reframe the manuscript.

\section{References}

Abouchami W, Boher M, Michard A, Albarède F, 1990. A major 2.1 Ga event of mafic magmatism in West Africa - An early stage of crustal accretion. J Geophys Res - Solid Earth 95: 17605-17629.

Adou M, Delor C, Siméon Y, et al. 1995. Carte géologique de la Côte d'Ivoire à 1/200 000 : Abengourou. Direction des Mines et de la Géologie.

Baratoux L, Metelka V, Naba S, Jessell MW, Grégoire M, Ganne J. 2011. Juvenile Paleoproterozoic crust evolution during the Eburnean orogeny (similar to 2.2-2.0 Ga), western Burkina Faso. Precambrian Res 191: 18-45.

Bedeaux P, Pilote P, Daigneault R, Rafini S. 2017. Synthesis of the structural evolution and associated gold mineralization of the Cadillac Fault, Abitibi, Canada. Ore Geol Rev 82: 49-69.

Berthé D, Choukroune P, Gapais D. 1979. Orientation préférentielle du quartz et orthogneissification progressive en régime cisaillant: 1'exemple du cisaillement sud-armoricain. Bull Mineral 102: 265-272.

Betts P, Williams H, Stewart J, Ailleres L. 2007. Kinematic analysis of aeromagnetic data: looking at geophysical data in a structural context. Gondwana Res 11: 582-583.

Block S, Baratoux L, Zeh A, et al. 2016a. Paleoproterozoic juvenile crust formation and stabilisation in the south-eastern West African Craton (Ghana); new insights from U-Pb-Hf zircon data and geochemistry. Precambrian Res 287: 1-30.
Block S, Ganne J, Baratoux L, et al. 2015. Petrological and geochronological constraints on lower crust exhumation during Paleoproterozoic (Eburnean) orogeny, NWGhana, West African Craton. Precambrian Res 33: 463-494.

Block S, Jessell M, Ailleres L, et al. 2016b. Lower crust exhumation during Paleoproterozoic (Eburnean) orogeny, NW Ghana, West African Craton: interplay of coeval contractional deformation and extensional gravitational collapse. Precambrian Res 274: 82-109.

Boher M, Abouchami W, Michard A, Albarède F, Arndt NT. 1992. Crustal growth in West Africa at 2.1 Ga. J Geophys Res - Solid Earth 97: 345-369.

Bonnard LF, Kagambega N, SYSMIN team. 2003. Carte géologique du Burkina Faso à 1/200 000 : Pô, NC-30-XXIII. BRGM.

Brun JP, Choukroune P. 1981. Déformation progressive et structures crustales. Rev Geogr Phys Geol Dyn 23: 177-193.

Bureau de Recherches Géologiques et Minières. 1963. Carte Géologique de reconnaissance de la Côte d'Ivoire à 1/500 000 : Katiola. Direction des Mines et de la Géologie.

Caby R, Delor C, Agoh O. 2000. Lithologie, structure et métamorphisme des formations birimiennes dans la région d'Odienné (Côte d'lvoire) : rôle majeur du diapirisme des plutons et des décrochements en bordure du craton de Man. J Afr Earth Sci 30: 351-374.

Cagnard F, Durrieu N, Gapais D, Brun JP, Ehlers C. 2006a. Crustal thickening and lateral flow during compression of hot lithospheres, with particular reference to Precambrian times. Terra Nova 18: 72-78.

Cagnard F, Brun J-P, Gapais D. 2006b. Modes of thickening of analogue weak lithospheres. Tectonophysics 421: 145-160.

Castaing C, Billa M, Milési JP, et al. 2003. Carte géologique et minière du Burkina Faso à 1/1 000 000. BRGM-BUMIGEB.

Chardon D, Choukroune P, Jayananda M. 1996. Strain patterns, décollement and incipient sagducted greenstone terrains in the Archaean Dharwar craton (south India). J Struct Geol 18: 991-1004.

Chardon D, Gapais D, Cagnard F. 2009. Flow of ultra-hot orogens: a view from the Precambrian, clues for the Phanerozoic. Tectonophysics 477: 105-118.

Chardon D, Grimaud JL, Beauvais A, Bamba O. 2018. West African lateritic pediments: landform-regolith evolution processes and mineral exploration pitfalls. Earth-Sci Rev 179: 124-146.

Chardon D, Jayananda M, Chetty TRK, Peucat JJ. 2008. Precambrian continental strain and shear zone patterns: South Indian case. J Geophys Res - Solid Earth 113: B08402.

Chardon D, Jayananda M, Peucat JJ. 2011. Lateral constrictional flow of hot orogenic crust: insights from the Neoarchean of south India, geological and geophysical implications for orogenic plateaux. Geochem Geophys Geosyst 12: Q02005.

Chèvremont $\mathrm{P}$, Donzeau M, Le Métour J, et al. 2003. Carte géologique du Burkina Faso à 1/200 000 : Koudougou, ND-30-IV. BRGM.

Choukroune P, Bouhallier H, Arndt NT. 1995. Soft lithosphere during periods of Archean crustal growth or crustal reworking. Spec Publ Geol Soc 95: 67-86.

Cochelin B, Chardon D, Denèle Y, Gumiaux C, Le Bayon B. 2017. Vertical strain partitioning in hot Variscan crust: Syn-convergence escape of the Pyrenees in the Iberian-Armorican syntax. Bull Soc Geol Fr 188: 39.

Cordani UG, Ramos VA, Fraga LM, et al. 2006. Tectonic map of South America at 1:5,900,000 scale. Commission for the Geological Map of the World. 
Cruden AR, Nasseri MHB, Pysklywec R. 2006. Surface topography and internal strain variation in wide hot orogens from threedimensional analogue and two-dimensional numerical vice models. Geol Soc Spec Publ 253: 79-104.

Debat P, Nikiema S, Mercier A, et al. 2003. A new metamorphic constraint for the Eburnean orogeny from Paleoproterozoic formations of the Man shield (Aribinda and Tampelga countries, Burkina Faso). Precambrian Res 123: 47-65.

Delor C, Diaby I, Siméon Y, et al. 1992. Carte géologique de la Côte d'Ivoire à 1/200 000 : Grand-Bassam. Direction des Mines et de la Géologie.

Delor C, Siméon Y, Vidal M, et al. 1995. Carte géologique de la Côte d'Ivoire à 1/200 000 : Nassian. Direction des Mines et de la Géologie.

Delor C, de Roever EWF, Lafon JM, et al. 2003a. The Bakhuis ultrahigh-temperature granulite belt (Suriname): Transamazonian crustal stretching in the revised Guiana shield framework. Géol Fr (2-3-4): 207-230.

Delor C, Lahondère D, Egal E, et al. 2003b. Transamazonian crustal growth and reworking as revealed by the 1:500,000-scale geological map of French Guiana (2nd edition). Géol Fr (2-3-4): 5-57.

Dewey JF, Holdsworth RE, Strachan RA. 1998. Transpression and transtension zones. Spec Publ Geol Soc 135: 1-14.

Duguet M, Lin S, Davis DW, Corkery MT, McDonald J. 2009. Longlived transpression in the Archean Bird River greenstone belt, western Superior Province, Southeastern Manitoba. Precambrian Res 174: 381-407.

Égal E, Thieblemont D, Lahondère D, et al. 2002. Late Eburnean granitization and tectonics along the western and northwestern margin of the Archean Kenema-Man domain (Guinea, West African Craton). Precambrian Res 117: 57-84.

Eglinger A, Thébaud N, Zeh A, et al. 2017. New insights into the crustal growth of the Paleoproterozoic margin of the Archean Kénéma-Man domain, West African craton (Guinea): implications for gold mineral system. Precambrian Res 292: 258-289.

Eisenlohr BN. 1989. The structural geology of Birimian and Tarkwaian rocks in Ghana. BGR Report 106: 448.

Eisenlohr BN, Hirdes W. 1992. The structural development of the Early Proterozoic Birimian and the Tarkwaian rocks of Southwest Ghana, West Africa. J Afr Earth Sci 14: 313-325.

Feybesse JL, Billa M, Guerrot C, et al. 2006. The paleoproterozoic Ghanaian province: geodynamic model and ore controls, including regional stress modeling. Precambrian Res 149: 149-196.

Feybesse JL, Milesi JP. 1994. The Archaean/Proterozoic Contact Zone in West-Africa - a mountain belt of decollement thrusting and folding on a continental-margin related to 2.1-Ga Convergence of Archean Cratons. Precambrian Res 69: 199-227.

Feybesse JL, Milesi JP, Ouédraogo MF, Prost A. 1990. La « ceinture » protérozoïque inférieur de Boromo-Goren (Burkina Faso) : un exemple d'interférence entre deux phases transcurrentes éburnéennes. C R Acad Sci Paris 310: 1353-1360.

Fontaine A, Eglinger A, Ada K, et al. 2017. Geology of the worldclass Kiaka polyphase gold deposit, West African Craton, Burkina Faso. J Afr Earth Sci 126: 96-122.

Frimmel HE. 2014. A giant mesoarchean crustal gold-enrichment episode: possible causes and consequences for exploration. Soc Econ Geol Spec Publ 18: 209-234.

Ganne J, De Andrade V, Weinberg RF, et al. 2012. Modern-style plate subduction preserved in the Palaeoproterozoic West African craton. Nature Geosci 5: 60-65.

Ganne J, Gerbault M, Block S. 2014. Thermo-mechanical modeling of lower crust exhumation-Constraints from the metamorphic record of the Palaeoproterozoic Eburnean orogeny, West African Craton. Precambrian Res 243: 88-109.

Gapais D. 2018. Tectonics-mineralisation relationships within weak continental lithospheres: a new structural framework for Precambrian cratons. BSGF-Earth Sci Bull 189: 14.

Gapais D, Balé P, Choukroune P, Cobbold PR, Mahjoub Y, Marquer D. 1987. Bulk kinematics from shear zone patterns - Some field examples. J Struct Geol 9: 635-646.

Gapais D, Fiquet G, Cobbold PR. 1991. Slip system domains. 3. New insights in fault kinematics from plane-strain sandbo experiments. Tectonophysics 188: 143-157.

Gapais D, Cobbold PR, Bourgeois O, Rouby D, de Urreiztieta M. 2000. Tectonic significance of fault-slip data. J Struct Geol 22: 881-888.

Gapais D, Potrel A, Machado N, Hallot E. 2005. Kinematics of longlasting Paleoproterozoic transpression within the Thompson Nickel Belt, Manitoba, Canada. Tectonics 24: TC3002.

Gapais D, Jaguin J, Cagnard F, Boulvais P. 2014. Pop-down tectonics, fluid channeling and ore deposits within ancient hot orogens. Tectonophysics 618: 102-106.

Gasquet D, Barbey P, Adou M, Paquette JL. 2003. Structure, Sr-Nd isotope geochemistry and zircon $\mathrm{U}-\mathrm{Pb}$ geochronology of the granitoids of the Dabakala area (Cote d'Ivoire) : evidence for a 2.3-Ga crustal growth event in the Palaeoproterozoic of West Africa? Precambrian Res 127: 329-354.

Ghana Geological Survey. 2008a. Geological map of Ghana at 1:100 000 scale: sheet 0503B. GGS, CGS, BRGM, GSD.

Ghana Geological Survey. 2008b. Geological map of Ghana at 1:100 000 scale: sheet 0803 B. GGS, CGS, BRGM, GSD.

Ghana Geological Survey. 2008c. Geological map of Ghana at 1:100 000 scale: sheet 0903D. GGS, CGS, BRGM, GSD.

Gibbs AK, Baron CN, 1993. The Geology of the Guiana shield. Oxford: Oxford University Press.

Grenholm M, Jessell M, Thébaud N. 2019. A geodynamic model for the Paleoproterozoic (ca. 2.27-1.96 Ga) Birimian Orogen of the southern West African Craton - Insights into an evolving accretionary-collisional orogenic system. Earth-Sci Rev 192: 138-193.

Griffis Consulting and Exploration Services, Watson Geophysics Ltd. 1998. Geology and Gold Occurrences of Southwestern Ghana at 1:500 000 scale. Minerals Commission of Ghana.

Hanmer S, Mengel F, Connelly J, vanGool J. 1997. Significance of crustal-scale shear zones and synkinematic mafic dykes in the Nagssugtoqidian orogen, SW Greenland: a re-examination. $J$ Struct Geol 19: 59-75.

Harris LB. 2003. Folding in high-grade rocks due to back-rotation between shear zones. J Struct Geol 25: 223-240.

Harris LB, Bédard J. 2014. Crustal evolution and deformation in a non-plate-tectonic Archaean Earth: comparisons with Venus. In Dilek Y, Furnes H, eds. Evolution of Archean Crust and Early Life. Springer, pp. 215-291.

Harris LB, Cobbold PR. 1985. Development of conjugate shear bands during bulk simple shearing. J Struct Geol 7: 37-44.

Hein KAA. 2010. Succession of structural events in the Goren greenstone belt (Burkina Faso): implications for West African tectonics. J Afr Earth Sci 56: 83-94.

Hein KAA, Morel V, Kagone O, Kiemde F, Mayes K. 2004. Birimian lithological succession and structural evolution in the Goren segment of the Boromo-Goren Greenstone Belt, Burkina Faso. $J$ Afr Earth Sci 39: 1-23.

Hudleston P. 1999. Strain compatibility and shear zones: is there a problem? J Struct Geol 21: 923-932. 
Hudleston PJ, Schultzela D, Southwick DL. 1988. Transpression in an Archean greenstone belt, Northern Minnesota. Can J Earth Sci 25: 1060-1068.

Jessell MW, Amponsah PO, Baratoux L, Asiedu DK, Loh GK, Ganne J. 2012. Crustal-scale transcurrent shearing in the Paleoproterozoic Sefwi-Sunyani-Comoe region, West Africa. Precambrian Res 212: $155-168$.

Jessell MW, Begg GC, Miller MS. 2016. The geophysical signatures of the West African Craton. Precambrian Res 274: 3-24.

Kouamelan AN, Delor C, Peucat JJ. 1997. Geochronological evidence for reworking of Archean terrains during the Early Proterozoic (2.1 Ga) in the western Côte d'Ivoire (Man Rise, West African Craton). Precambrian Res 86: 177-199.

Kouamelan AN, Kra KSA, Djro SC, Paquette JL, Peucat JJ. 2018. The Logouale Band: a large Archean crustal block in the Kenema-Man domain (Man-Leo rise, West African Craton) remobilized during Eburnean orogeny (2.05 Ga). J Afr Earth Sci 148: 6-13.

Kroonenberg SB, de Roever EWF, Fraga LM, et al. 2016. Paleoproterozoic evolution of the Guiana Shield in Suriname: a revised model. Netherlands J Geosci 95: 491-522.

Ledru P, Johan V, Milesi JP, Tegyey M. 1994. Markers of the Last Stages of the Palaeoproterozoic Collision - Evidence for a 2-Ga continent involving circum South-Atlantic Provinces. Precambrian Res 69: 169-191.

Lompo M. 2009. Geodynamic evolution of the 2.25-2.0 Ga Palaeoproterozoic magmatic rocks in the Man-Leo Shield of the West African Craton. A model of subsidence of an oceanic plateau. Spec Publ Geol Soc 323: 231-254.

Lompo M. 2010. Paleoproterozoic structural evolution of the ManLeo Shield (West Africa). Key structures for vertical to transcurrent tectonics. J Afr Earth Sci 58: 19-36.

Martelat JE, Lardeaux JM, Nicollet C, Rakotondrazafy R. 2000. Strain pattern and late Precambrian deformation history in southern Madagascar. Precambrian Res 102: 1-20.

McFarlane HB, Ailleres L, Betts P, et al. 2019. Episodic collisional orogenesis and lower crust exhumation during the Palaeoproterozoic Eburnean Orogeny: evidence from the Sefwi Greenstone Belt, West African Craton. Precambrian Res 325: 88-110.

Metelka V, Baratoux L, Naba S, Jessell MW. 2011. A geophysically constrained litho-structural analysis of the Eburnean greenstone belts and associated granitoid domains, Burkina Faso, West Africa. Precambrian Res 190: 48-69.

Milési JP, Feybesse JL, Ledru P, et al. 1989. Les minéralisations aurifères de l'Afrique de l'Ouest. Leurs relations avec l'évolution lithostructurale du Protérozoïque inférieur. Chron Rech Min 497: 3-98.

Milési JP, Frizon de Lamotte D, De Kock F, Toteu F. 2010. Tectonic Map of Africa at 1:10,000,000 scale. Commission for the Geological Map of the World.

Milési JP, Ledru P, Feybesse JL, Dommanget A, Marcoux E. 1992. Early Proterozoic Ore-Deposits and Tectonics of the Birimian Orogenic Belt, West Africa. Precambrian Res 58: 305-344.

Mortimer J. 1992. The Kan River gneiss terrane of Central Côte d'Ivoire - Mylonitic remnants of an ancient magmatic arc. J Afr Earth Sci 15: 353-367.

Naba S, Lompo M, Debat P, Bouchez JL, Beziat D. 2004. Structure and emplacement model for late-orogenic Paleoproterozoic granitoids: the Tenkodogo-Yamba elongate pluton (Eastern Burkina Faso). J Afr Earth Sci 38: 41-57.

Nikiema SJ, 1992. Évolution tectonique et magmatique du Protérozoïque inférieur du sillon de Djibo (Burkina Faso) au sein du craton ouest africain. Un exemple de tectonique polycyclique et contrôle structural de la minéralisation aurifère. Ph D Thesis, Dakar: Cheik Anta Diop University.

Nomade S, Chen Y, Pouclet A, et al. 2003. The Guiana and the West African shield Palaeoproterozoic grouping: new palaeomagnetic data for French Guiana and the Ivory Coast. Geophys J Int 154: 677-694.

Onstott TC, Hargraves RB. 1981. Proterozoic transcurrent tectonics Paleomagnetic evidence from Venezuela and Africa. Nature 289: 131-136.

Onstott TC, Hargraves RB, York D, Hall C. 1984. Constraints on the motions of South American and African shields during the Proterozoic. 1. Ar39-Ar40 and paleomagnetic correlations between Venezuela and Liberia. Geol Soc Am Bull 95: 1045-1054.

Ouédraogo OF, SYSMIN team. 2003. Carte géologique du Burkina Faso à 1/200 000 : Boulsa, ND-30-VI. BRGM.

Parra-Avila LA, Belousova E, Fiorentini ML, Eglinger A, Block S, Miller J. 2018. Zircon Hf and O-isotope constraints on the evolution of the Paleoproterozoic Baoule-Mossi domain of the southern West African Craton. Precambrian Res 306: 174-188.

Parra-Avila LA, Kemp AIS, Fiorentini ML, et al. 2017. The geochronological evolution of the Paleoproterozoic Baoule-Mossi domain of the Southern West African Craton. Precambrian Res 300: 1-27.

Perrouty S, Ailleres L, Jessell MW, Baratoux L, Bourassa Y, Crawford B. 2012. Revised Eburnean geodynamic evolution of the gold-rich southern Ashanti Belt, Ghana, with new field and geophysical evidence of pre-Tarkwaian deformations. Precambrian Res 204: 12-39.

Petersson A, Schersten A, Gerdes A. 2018. Extensive reworking of Archaean crust within the Birimian terrane in Ghana as revealed by combined zircon U-Pb and Lu-Hf isotopes. Geosci Front 9: 173-189.

Pitra P, Kouamelan AN, Ballèvre M, Peucat JJ. 2010. Palaeoproterozoic high-pressure granulite overprint of the Archean continental crust: evidence for homogeneous crustal thickening (Man Rise, Ivory Coast). J Metam Geol 28: 41-58.

Platt JP, Passchier CW. 2016. Zipper junctions: a new approach to the intersections of conjugate strike-slip faults. Geology 44: 795-798.

Ponsard JF, Roussel J, Villeneuve M, Lesquer A. 1988. The PanAfrican orogenic belt of Southern Mauritanides and Northern Rokelides (Southern Senegal and Guinea, West Africa) - Gravity evidence for a collisional suture. J Afr Earth Sci 7: 463-472.

Siméon Y, Delor C, Zeade Z, et al. 1995. Carte géologique de la Côte d'Ivoire à 1/200 000 : Agnibilekrou Kouamé-Dari. Direction des Mines et de la Géologie.

Thiéblemont D, ed. 2016. Geological map of Africa at 1:10,000,000 scale. Commission for the Geological Map of the World.

Thompson AB, Schulmann K, Jezek J. 1997. Thermal evolution and exhumation in obliquely convergent (transpressive) orogens. Tectonophysics 280: 171-184.

Tikoff B, Teyssier C. 1994. Strain modeling of displacement field partitioning in transpressionnal orogens. J Struct Geol 16: 1575-1588.

Tikoff B, Greene D. 1997. Stretching lineations in transpressional shear zones: an example from the Sierra Nevada Batholith, California. J Struct Geol 19: 29-39.

Tikoff B, Wojtal SF. 1999. Displacement control of geologic structures. J Struct Geol 21: 959-967.

Treloar PJ, Blenkinsop TG. 1995. Archaean deformation patterns in Zimbabwe: true indicators of Tibetan-style crustal extrusion or not? Geol Soc Spec Publ 95: 87-108. 
Trinquard R, Kagambega N, Naba S, SYSMIN team. 2003. Carte géologique du Burkina Faso à 1/200 000 : Tenkodogo, NC-30XXIV. BRGM.

Tshibubudze A, Hein KAA. 2013. Structural setting of gold deposits in the Oudalan-Gorouol volcano-sedimentary belt east of the Markoye Shear Zone, West African Craton. J Afr Earth Sci 80: 31-47.

Tshibubudze A, Hein KAA, Marquis P. 2009. The Markoye Shear Zone in NE Burkina Faso. J Afr Earth Sci 55: 245-256.

Vanderhaeghe O, Ledru P, Thieblemont D, et al. 1998. Contrasting mechanism of crustal growth - Geodynamic evolution of the Paleoproterozoic granite-greenstone belts of French Guiana. Precambrian Res 92: 165-193.

Vegas N, Naba S, Bouchez JL, Jessell M. 2008. Structure and emplacement of granite plutons in the Paleoproterozoic crust of Eastern Burkina Faso: rheological implications. Int J Earth Sci 97: 1165-1180.

Vidal M, Delor C, Pouclet A, Simeon Y, Alric G. 1996. Évolution géodynamique de l'Afrique de l'Ouest entre 2,2 et 2,0 Ga: le style «archéen» des ceintures de roches vertes et des ensembles sédimentaires birimiens du nord-est de la Côte d'Ivoire. Bull Soc Geol Fr 167: 307-319.
Vidal M, Gumiaux C, Cagnard F, Pouclet A, Ouattara G, Pichon M. 2009. Evolution of a Paleoproterozoic "weak type" orogeny in the West African Craton (Ivory Coast). Tectonophysics 477: 145-159.

Wane O, Liegeois JP, Thébaud N, Miller J, Metelka V, Jessell M. 2018. The onset of the Eburnean collision with the Kenema-Man craton evidenced by plutonic and volcanosedimentary rock record of the Masssigui region, southern Mali. Precambrian Res 305: 444-478.

Williams HR, Culver SJ. 1988. Structural terranes and their relationships in Sierra Leone. J Afr Earth Sci 7: 473-477.

Woodman KK, Baratoux L, Somda A, Siebenaller L. 2016. The Youga gold deposit, Burkina Faso. Ore Geol Rev 78: 631-638.

Ye J, Chardon D, Rouby D, et al. 2017. Paleogeographic and structural evolution of northwestern Africa and its Atlantic margins since the early Mesozoic. Geosphere 13: 1254-1284.

Zeade Z, Delor C, Siméon Y, et al. 1995. Carte géologique de la Côte d'Ivoire à 1/200 000 : Bondoukou. Direction des Mines et de la Géologie.

Zitzmann A, ed. 1998. Geological, geophysical and geochemical investigations in the Bui Belt area in Ghana. Geol Jahrb (B) 88: $1-269$.

Cite this article as: Chardon D, Bamba O, Traoré K. 2020. Eburnean deformation pattern of Burkina Faso and the tectonic significance of shear zones in the West African craton, BSGF - Earth Sciences Bulletin 191: 2. 